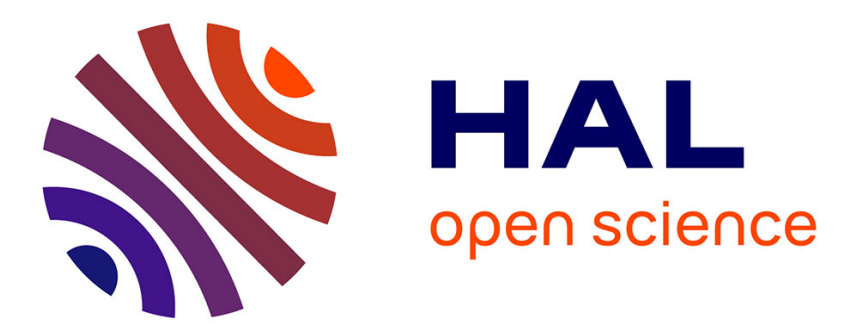

\title{
Land use development and environmental responses since the Neolithic around Lake Paladru in the French Pre-alps
}

E Doyen, C Bégeot, Anaëlle Simonneau, Laure Millet, Emmanuel Chapron, Fabien Arnaud, B Vannière

\section{To cite this version:}

E Doyen, C Bégeot, Anaëlle Simonneau, Laure Millet, Emmanuel Chapron, et al.. Land use development and environmental responses since the Neolithic around Lake Paladru in the French Pre-alps. Journal of Archaeological Science, 2016, 7, pp.48-59. 10.1016/j.jasrep.2016.03.040 . hal-01326183

\section{HAL Id: hal-01326183 \\ https://hal.science/hal-01326183}

Submitted on 3 Jun 2016

HAL is a multi-disciplinary open access archive for the deposit and dissemination of scientific research documents, whether they are published or not. The documents may come from teaching and research institutions in France or abroad, or from public or private research centers.
L'archive ouverte pluridisciplinaire HAL, est destinée au dépôt et à la diffusion de documents scientifiques de niveau recherche, publiés ou non, émanant des établissements d'enseignement et de recherche français ou étrangers, des laboratoires publics ou privés. 


\title{
Land use development and environmental responses since the Neolithic around Lake Paladru in the French Pre-alps
}

\author{
E. Doyen ${ }^{\text {a }}$, C. Bégeot ${ }^{\text {a }}$, A. Simonneau ${ }^{\text {b }}$, L. Millet ${ }^{\text {a }}$, E. Chapron ${ }^{\text {c }}$, F. Arnaud ${ }^{\mathrm{d}}$, B. Vannière ${ }^{\mathrm{a}}$ \\ a Laboratoire Chrono-Environnement, Université Bourgogne Franche Comté, CNRS, F-25030 Besançon Cedex, France \\ b Institut des Sciences de la Terre d'Orléans, Université d'Orléans, CNRS, F-45100 Orléans, France \\ c Laboratoire GEODE, Université Toulouse Jean Jaurès, CNRS, F-31058 Toulouse Cedex 1, France \\ d Environnements Dynamiques et Territoires de la Montagne, Université Savoie Mont Blanc, CNRS, F-73370 Chambéry, France
}

\section{A R T I C L E I N F O}

\section{Article history:}

Received 14 December 2015

Received in revised form 18 March 2016

Accepted 23 March 2016

Available online $\mathrm{xxxx}$

\section{Keywords:}

Land use history

Vegetation dynamics

Fire practices

Soil erosion

France

Alps

Holocene

\begin{abstract}
A B S T R A C T
The Lake Paladru sedimentary archive documents the past 10,000 years of the environmental history of the French Pre-alps. The archive's information on vegetation dynamics, fire activity and soil erosion serves to reconstruct a continuous dynamic record of land use over the last 6000 years. This multi-proxy approach serves to document the effects of successive human settlements on the environment at the watershed scale. First, discrete human impacts were identified during the Middle Neolithic that have not yet been confirmed by archaeological discoveries in the watershed. Developments of agropastoral activity have been recorded during the Late Neolithic (the period of the pile-dwelling archaeological site "Les Baigneurs") and the Bronze Age, and the practice of slashand-burn is documented by the records of fires. During the Iron Age and the Roman period, agropastoral activities (livestock farming and cereal cultivation) became continuous. They involved an intensification of human effects with a rapid and high-amplitude increase in soil erosion and a shift in the use of fire from an instrument for clearing land to an agropastoral landscape management tool. The Medieval period was characterized by the spatial expansion and diversification of crops. Results of this study have located the "thousand-year" pile dwelling sites such as "Colletière" in a longer phase of human occupation that deeply and sustainably modified the surrounding landscape of the lake. Beginning in the Modern period, the proxies used in this study served to record a new shift in land use marked by extensive clearing and the abandonment of most crop areas. This shift was linked to the expansion of industrial activities and subsequently to their abandonment during the 20th century.
\end{abstract}

(c) 2016 Elsevier Ltd. All rights reserved.

\section{Introduction}

Human effects on ecosystems have increased exponentially over the past few centuries, and the development of an overview of this increase in anthropogenic forcing from a long-term perspective is now a major challenge for palaeoenvironmental studies (Dearing and Jones, 2003; Dearing, 2006; Seddon et al., 2014). Since the beginning of agricultural development in the Neolithic until the present, humans have never stopped shaping their environment to obtain required resources. Over millennia, they were able to change their environmental modes of operation and to adapt their technology and techniques to changing socio-economic and political contexts but also to variable climate and local environmental conditions (Doyen et al., 2013a,b; Enters et al., 2008; Ledger et al., 2015). Thus, it appears necessary to retrace the history of land use to determine the amplitude and variability of anthropogenic impacts on ecosystems by means of comparative studies that confront past ecological and climate dynamics with archaeological evidence associated with human settlements.

Lake systems are suitable for this type of enquiry due to the favourable conditions that they provide for the preservation of both palaeoenvironmental markers and archaeological remains. Piledwelling sites discovered on the borders of alpine, subalpine and Jurassian lakes represent privileged archives for studying human/environment relationships (Brochier et al., 2007; Gauthier et al., 2008; Jacomet, 2009; Magny, 1993; Pétrequin and Pétrequin, 1988; Richard, 1997; Rösch, 1992). The palaeoenvironmental study of a sediment core collected in the central portion of a lake, beyond a strict archaeological context, appears to complement other data well in approaching these relationships, not only focused on one site and over a limited period but at the scale of an entire catchment and over long periods of time. Sediment records serve to integrate the effect on the ecosystem of all archaeological sites that are dispersed within a watershed.

Lake Paladru (Isère, France) offers a privileged framework for addressing these human-environment interaction issues as they emerge and persist throughout the Holocene (Bocquet, 2012; Brochier et al., 2007; Simonneau et al., 2013). The local archaeological context is particularly rich and well documented by numerous archaeological studies conducted at pile-dwelling sites (Bocquet, 1987, 2012; Colardelle and Verdel, 1993), field explorations, and research in historical archives within the catchment area. The main objectives of the present paper 
are (i) to identify the different phases of human influence in the watershed of Lake Paladru; (ii) to characterize their successive effects on the ecosystem over the past 10,000 years, comparing plant, fire and soil erosion dynamics with available archaeological data; (iii) to determine how fire activity have been influenced by land use changes over time.

\section{Settings}

\subsection{Environmental settings}

Lake Paladru $\left(5^{\circ} 32^{\prime} 06^{\prime \prime} \mathrm{E}, 45^{\circ} 27^{\prime} 18^{\prime \prime} \mathrm{N}\right)$ is located at $492 \mathrm{~m}$ a.s.l in the French Alpine foreland (Fig. 1a). This moraine-dammed lake $\left(3.92 \mathrm{~km}^{2}\right.$, $5 \mathrm{~km}$ long and $0.7 \mathrm{~km}$ wide) was formed during the Last Glacial Maximum (Fig. 1b). The lake is fed by 2 streams to the west and to the north (the Surand and the Courbon Rivers), and the lake waters drain into one stream (the Fure River) on its southern edge. Currently, the water depth is artificially maintained by a valve system (introduced in AD 1868) at a depth of approximately $36 \mathrm{~m}$.

The watershed has an area of $55 \mathrm{~km}^{2}$ and is bordered by hills reaching 660 to $780 \mathrm{~m}$ a.s.l. The bedrock is formed primarily by Miocene molasses of the alpine belt, covered in several places by Pleistocene moraines and modern alluvial deposits. The vegetation cover consists of grasslands, fields and deciduous forests (Alnus glutinosa, Carpinus betulus, Castanea sativa, Fagus sylvatica, Fraxinus excelsior, Quercus petraea, Quercus pubescens and Quercus robur). The area has a sub-continental climate: the mean annual precipitation rate is $1160 \mathrm{~mm}$ per year, while the mean July and January temperatures are $19{ }^{\circ} \mathrm{C}$ and $2{ }^{\circ} \mathrm{C}$, respectively.

\subsection{Archaeological and historical settings}

The oldest lakeshore settlement dates from the Late Neolithic and is located on a site named "Les Baigneurs" (Fig. 1c). This site was occupied twice between 2750 and 2650 BC (Bocquet, 1974; Bocquet et al., 1987). Two artefacts, a hook and a wooden pile, dated ca. 1100-900 BC, suggested a human presence around Lake Paladru during the Bronze Age (Bocquet, 2012). No settlement is locally documented for the Iron Age period, but artefacts dated from the 1st century $\mathrm{BC}$ to the $4-5$ th centuries $\mathrm{AD}$ and occurring at 12 sites located primarily in the littoral zone of the lake attested to new settlements during the Roman period (Dècle and Verdel, 2012) (Fig. 1c). The first lakeshore Medieval remains corresponding to 3 contemporary villages (fortified and aristocratic settlements with agricultural and handicraft activities) were occupied from AD to AD (Colardelle and Verdel, 1993; Fig. 1c). After AD , the high density of sites identified within the watershed ( 5 castle mounds and 4 sites with earthen fortifications) reflected the construction of many small centres of power. At the end of the 11th century AD and at the beginning of the 12 th century $A D$, power was centralized by more powerful lords. The fortified sites were abandoned or reused and replaced by powerful castles (Clermont, Paladru and Virieu). Habitats and rural activities were then grouped permanently in the vicinity of these main castles (Colardelle and Verdel, 2002). During the 12th century $\mathrm{AD}$, the establishment of the monastery Silve Bénite (northwest of the lake) markedly influenced the geography of the human population. An additional influence on the areas human geography was the installation of handcraft sites beginning in the 14th century AD (ironworks, water-powered sawmill, textile crafts, fulling mill) in valley bottoms to take advantage of hydraulic power (Colardelle and Verdel, 2002). During the 19th century AD, the Industrial Revolution accelerated the development of the valleys (paper mills, weaving, sawmill and metalworking industry). Such activities continued to contribute to the economic and social life of the area until the 20th century AD.

\section{Materials and methods}

\subsection{Coring and geophysical logging}

The sedimentary infill of the lake was imaged by high-resolution seismic profiling with a sub-bottom profiler operating at $12 \mathrm{kHz}$ deployed on an inflatable boat and coupled with GPS navigation. Several profiles were made and used to select the location for the coring site PAL $09\left(5^{\circ} 32^{\prime} 348^{\prime \prime} \mathrm{E}-45^{\circ} 27^{\prime} 478^{\prime \prime} \mathrm{N}\right)$ characterized by continuous sedimentation and devoid of major landslides (Chapron et al., 2015; Simonneau et al., 2013). Five overlapping cores were taken at the deepest part of the basin (30 m deep) (Fig. 1b) using a stationary piston corer (UWITEC system) operated from a surface platform.

Along the $12 \mathrm{~m}$ length of the cores, magnetic susceptibility and gamma density were measured every $5 \mathrm{~mm}$ with a Multi Sensor Core Logger (Geotek). Sediment colour variations were checked using highresolution pictures. These 3 parametres were used to correlate the sedimentary units of core sections to create a master core without gaps (PAL09-MC). All further analyses were performed on the first $4 \mathrm{~m}$ of the PAL09-MC sequence which correspond to the Holocene period.

Geochemical core logging was performed by X-ray fluorescence using an ITRAX core scanner (CEREGE laboratory, Aix-en-Provence, France) to track the occurrences of allochtonous mineral inputs. The relative abundances of $\mathrm{Ca}, \mathrm{Si}, \mathrm{Ti}, \mathrm{K}, \mathrm{Fe}$ and $\mathrm{Al}$ were measured all along the sequence PAL09-MC using a chromium tube with the same setting ( $30 \mathrm{kV}, 12 \mathrm{~mA}$ ), a count-time of $15 \mathrm{~s}$ and a sampling step of $5 \mathrm{~mm}$.

\subsection{Chronology}

The chronological control was based on a combination of (i) 14 radiocarbon dates obtained at the Poznan Radiocarbon Laboratory and at the Laboratory LMC14 in Gif-sur-Yvette on diverse macro-remains of terrestrial origin (leaf, seed and wood), (ii) 3 ages estimated for the main late-glacial/early-Holocene transitions indicated by the pollen stratigraphy and the geochemistry data and (iii) radiometric markers (210Pb, 137Cs) measured every $5 \mathrm{~mm}$ for the topmost $16 \mathrm{~cm}$ (Doyen et al., 2015; Simonneau et al., 2013). An age-depth model within a 95\% confidence envelope was constructed using the R script Clam (loess model; Blaauw, 2010; Fig. 2). The description of the age-depth model and the explanations about the two rejected radiocarbon date are available in Doyen et al. (2015).

\subsection{Pollen analyses}

A total of 48 sediment subsamples, each $2 \mathrm{~cm}$ thick with a volume of $1.8 \mathrm{~cm}^{3}$ were taken at $8 \mathrm{~cm}$ intervals along core PAL09-MC. They were prepared for pollen analysis using the standard procedure described by Faegri and Iversen (1989). Pollen grains were identified and counted under $500 \times$ microscopy. Between 300 and 600 pollen grains of terrestrial plants (TLP, Total Land Pollen) were counted in each subsample excluding the dominant taxon. Pollen identification was performed using determination keys (Beug, 2004), books of photographs (Reille, 1992) and a reference collection of modern pollen types. Pollen counts were expressed as percentages of TLP excluding pteridophytes, aquatics and Cannabis/Humulus pollen types from the total pollen sum. Pollen data were divided in Local Pollen Assemblage Zones (LPAZ) via constrained incremental sums of squares cluster analysis (CONISS) performed from the relative abundance of pollen taxa. The broken stick criterion was used to select significant LPAZ.

\subsection{Charcoal analyses}

For microscopic charcoal analysis, 200 contiguous sediment subsamples, each $2 \mathrm{~cm}$ thick and with a volume of $2 \mathrm{~cm}^{3}$ were taken along core PAL09-MC. Micro-charcoal particles were extracted using the procedure 


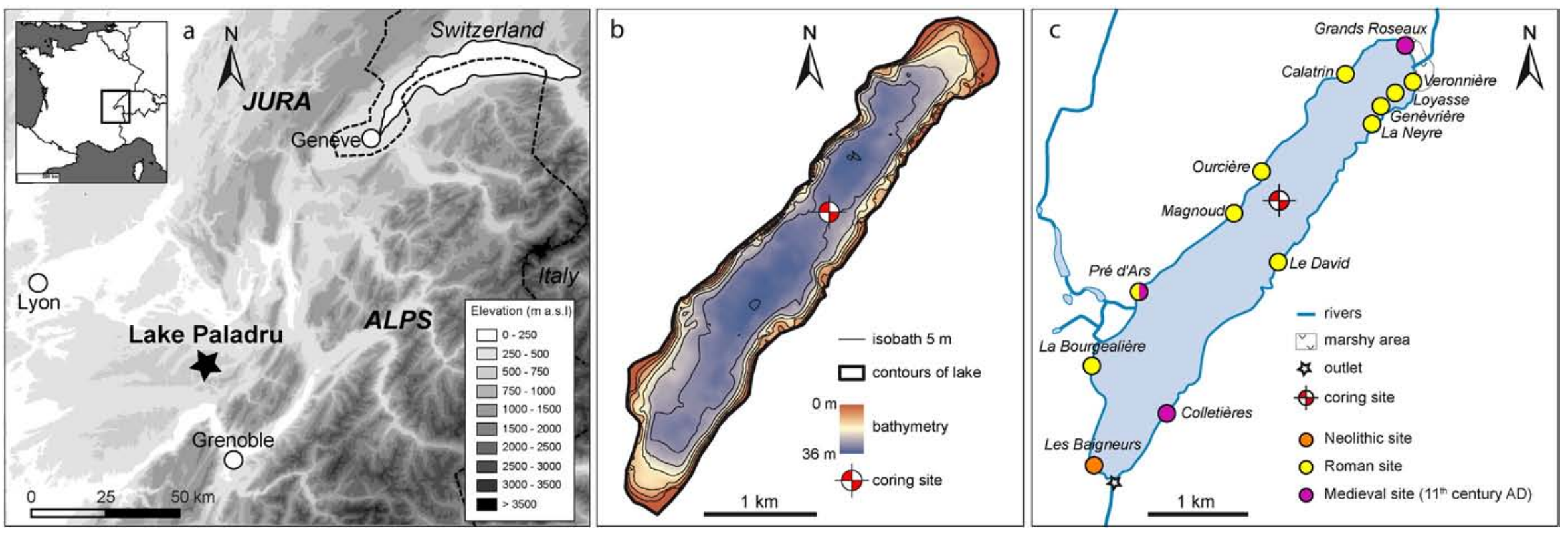

Fig. 1. a) Location of Lake Paladru, b) Bathymetric map of the lake and location of the core samples, c) Archaeological context from the shores of Lake Paladru. 


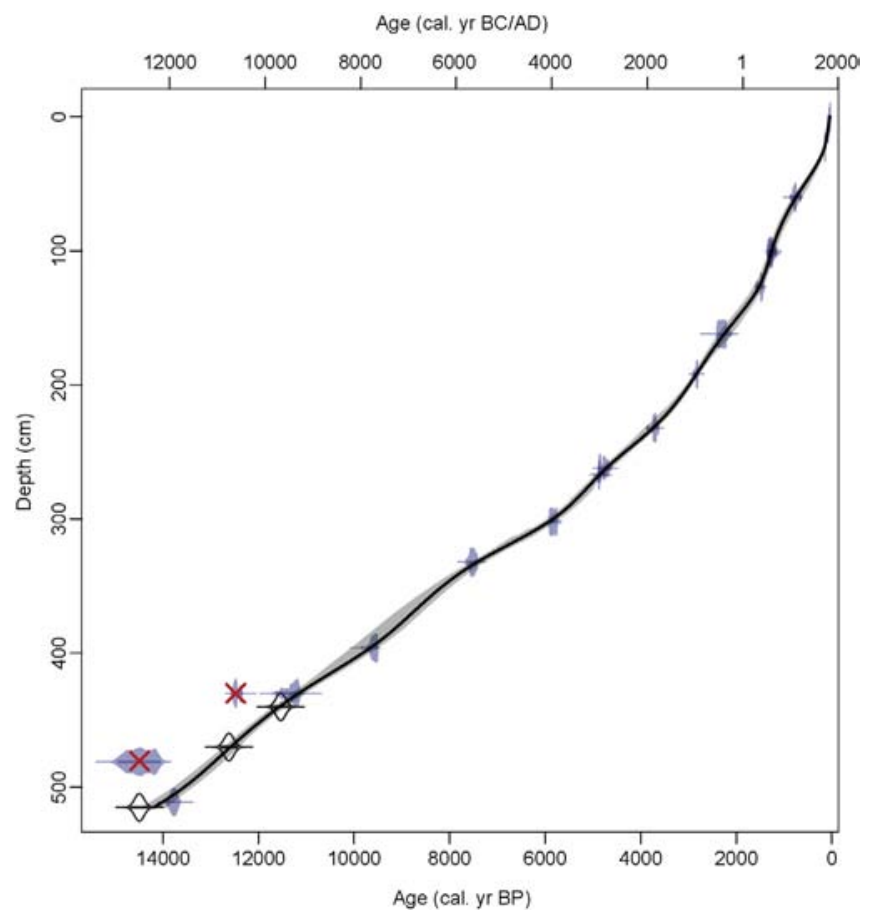

Fig. 2. Age depth-model with expected ages ( $2 \sigma$ calibration interval, in blue), ages fixed by pollen and sedimentation transition (in white) and rejected ages (crossed in red) along the sequence (bold line) with $95 \%$ confidence intervals (grey line). (For interpretation of the references to colour in this figure legend, the reader is referred to the web version of this article.)

described by Turner et al. (2008), which involves the removal of carbonates using $\mathrm{HCl}$, bleaching of non-charred organic material with $\mathrm{H}_{2} \mathrm{O}_{2}$, sieving to $200 \mu \mathrm{m}$ and density separation using LST (lithium heteropolytungstate with a specific density of 2.5). Lycopodium clavatum tablets were added to each subsample to estimate the concentration of charcoal in the sediment (Stockmaar, 1971). Microcharcoals were identified under transmitted light as black and opaque particles with angular contours (Clark, 1988). Identifications were checked using reflective light (using an oil immersion technique) to distinguish micro-charcoal from black opaque non-reflective organic matter. Charcoal measurements (area, length and width) were performed using image analysis software (Qwin Standard). The past regional fire activity (within a radius of ca. 20-50 km around the lake; Tinner et al., 1998) was reconstructed by calculating charcoal accumulation rates (micro-CHAR in $\mathrm{mm}^{2} \mathrm{~cm}^{-2} \mathrm{yr}^{-1}$ ).

For macroscopic charcoal analysis, 280 contiguous sediment subsamples with 1 to $2 \mathrm{~cm}$ thick and $2 \mathrm{~cm}^{3}$ were taken along core PAL09-MC. Charcoal particles were extracted by soaking samples in $\mathrm{HCl}(10 \%)$, in $\mathrm{H}_{2} \mathrm{O}_{2}(10 \%)$ and by sieving the samples at $200 \mu \mathrm{m}$ (Rhodes, 1998). Charcoal particles were counted and measured under a binocular microscope at $50 \times$ magnification with a reticule grid of $62.5 \times 10^{-3} \mathrm{~mm}^{2}(10 \times 10$ squares $)$. Charcoal identification was based on criteria defined by Umbanhowar and McGrath (1998). The past local fire activity (within an approximate radius of 1 to $2 \mathrm{~km}$ around the lake; Higuera et al., 2007) was reconstructed by calculating the charcoal accumulation rates (macro-CHAR in $\mathrm{mm}^{2} \mathrm{~cm}^{-2} \mathrm{yr}^{-1}$ ).

From 8000 BC to the present, the mean resolution of the microscopic charcoal analysis was 50 years per sample; the mean resolution of the macroscopic charcoal analysis was 38 years per sample.

To calculate the fire frequency, the macro-charcoal series was analysed using the method of charcoal signal decomposition developed by Blarquez et al. (2013), adapted from Higuera et al. (2009). The analysis of the sedimentary charcoal records comprised three main analytical steps (Higuera et al., 2009): 1 - Charcoal records were quantified into Charcoal Accumulation Rates (CHAR) using the sediment agedepth model to obtain charcoal values for equivalent time steps (corresponding to the median temporal resolution interval of the records) and volumes along the sedimentary sequence (Long et al., 1998); 2 - CHAR were filtered using diverse smoothing methods to model the background component. The background was used to reconstruct local biomass burned trends (Ali et al., 2012). The background was then subtracted from the CHAR to obtain the residual high frequency peaks; 3 - The peaks were decomposed into 2 sub-populations using a Gaussian mixture model, with the first part being related to noise and the second part representing the occurrence of local fire episodes (Gavin et al., 2006). The term "fire episodes" corresponds here to particular episodes from the charcoal peaks that could represent one or more fires occurring in the lakes' catchments ( $<1 \mathrm{~km}$ distance; Higuera et al., 2007). Charcoal peaks were used to reconstruct local fire frequency trends.

\section{Results}

\subsection{Vegetation record}

Seven LPAZ (i.e., Local Pollen Assemblage Zones) were identified in the pollen diagram (Fig. 3) using cluster analysis.

In LPAZ 1 (from 8300 to 6500 BC), Quercus, with a value of 40\%, dominated the tree and shrub percentages (85-90\%), Corylus and Ulmus remained stable at approximately $15 \%$ and approximately $5 \%$, respectively. Acer, Juniperus, Betula, Alnus and Salix were all below 5\%. Pinus decreased from $30 \%$ to $10 \%$. Among the herb taxa, Poaceae and Cyperaceae were the most numerous, reaching approximately $5 \%$.

In LPAZ 2 (from 6500 to $4200 \mathrm{BC}$ ), Quercus decreased from $40 \%$ to $20 \%$, Tilia decreased from $10 \%$ to 3\%, while Ulmus (10\%) and Fraxinus (10\%-15\%) increased. The percentages of Corylus and Pinus remained at the same order of magnitude as in the previous zone. The pollens of Abies, Fagus and Taxus appeared. The Abies percentages increased beginning at $6000 \mathrm{BC}$, the Taxus percentages increased beginning at $5000 \mathrm{BC}$, and the percentages of Fagus remained low. Salix and Betula remained under 5\% while Alnus increased slightly to 5\%. Juniperus pollens increased approximately $5 \%$ at the end of the zone. The herb percentages, varying between $5 \%$ and $10 \%$, were dominated by Poaceae.

In LPAZ 3 (from 4200 to 1200 BC), Abies and Fagus percentages strongly increased with fluctuating values between $15 \%$ and $40 \%$. Fraxinus, Ulmus, Tilia and Taxus percentages decreased beginning 2700 BC, while those of other trees (Quercus, Pinus and Corylus) remained relatively stable. Discontinuous occurrences of Juniperus were recorded. AP/TLP declined from $90 \%$ to $80 \%$ due to the slight increase of Poaceae percentages and the concomitant occurrences of several ruderal and pasture weeds. The first pollens of cereals appeared, and occurrences (from 4100 to $3000 \mathrm{BC}$; at $2550 \mathrm{BC}$; from 1300 to $1150 \mathrm{BC}$ ) were regularly recorded.

In LPAZ 4 (from 1200 to $500 \mathrm{BC}$ ), Abies decreased from $15 \%$ to $3 \%$. The percentages of Betula and Corylus increased slightly. Quercus and Fagus trees dominated with percentages of approximately $20 \%$ and those of Alnus, Pinus, Ulmus, Acer and Fraxinus remained stable under 10\%. At $850 \mathrm{BC}$, the pollens of Tilia and Taxus disappeared and the pollens of Carpinus appeared. The herbs were primarily represented by Poaceae (10\%), ruderal and pasture weeds. Only one occurrence of cereal was recorded, at the beginning of the zone.

In LPAZ 5 (from 500 BC to AD 900), Quercus reached a peak of $40 \%$, and then decreased to 15\%. The percentages of Alnus, Ulmus, Fraxinus and Fagus decreased at the beginning of the zone and increased again at the middle of the zone along with the percentages of Pinus, Abies and Carpinus. Corylus increased and remained at approximately $10 \%$; Betula percentages recorded several increases. The Juniperus curve became continuous, and low occurrences of Castanea and Juglans were recorded. The proportion of herbs increased, primarily Poaceae, which reached $15 \%$. Among the records of ruderal and pasture weeds, the 


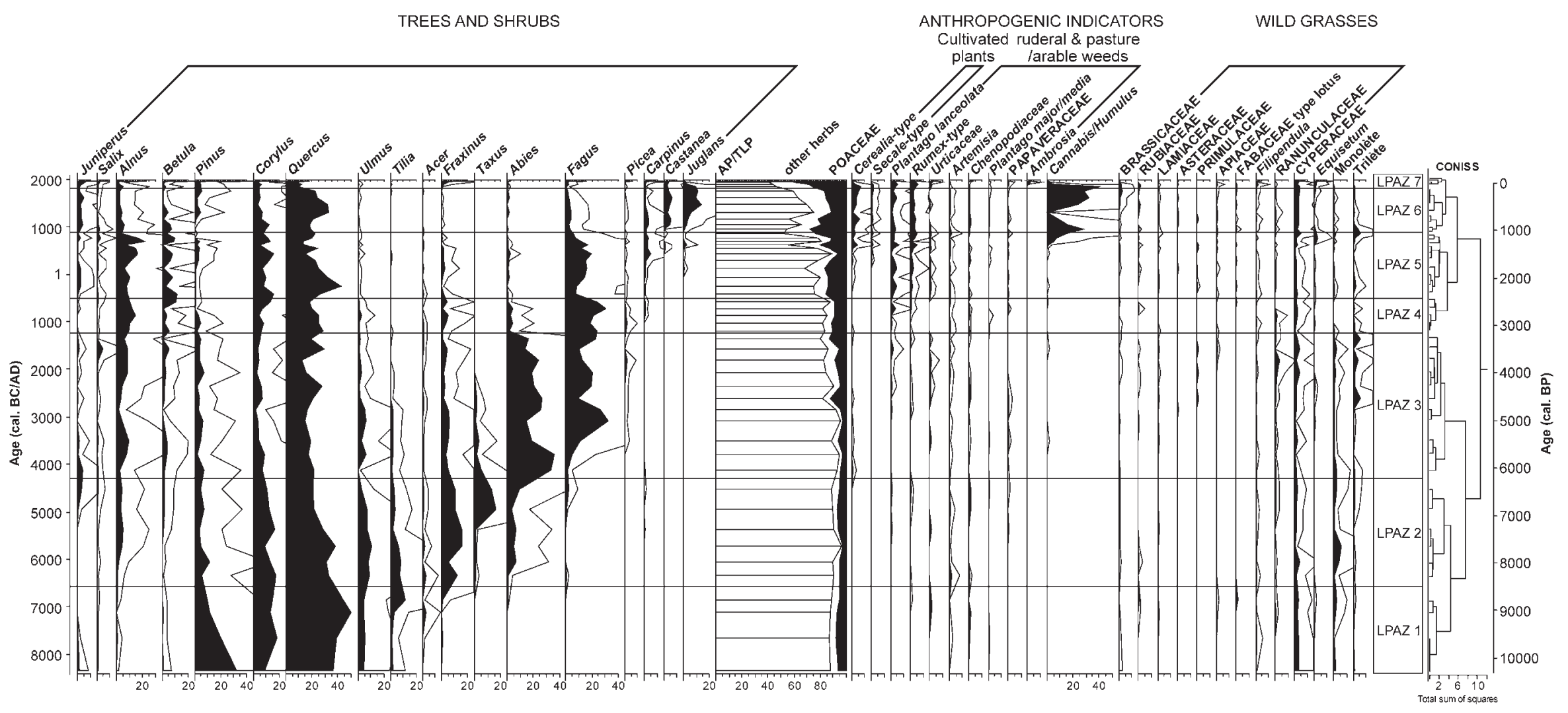

Fig. 3. Synthetic pollen diagram of Lake Paladru PAL09-MC core (in \%) with exaggerated curves $\times 5$ (solid line), AP/TLP: Arboreal Pollen/Total Land Pollen. The pollen diagram was subdivided into local pollen assemblage zones (LPAZ). 
Plantago lanceolata and Rumex-type percentages increased and showed a steady presence until the top of the sequence. Cerealia-type percentages increased and were recorded continuously, as was Cannabis, from $A D 600$ to the end of LPAZ 5. The first Secale-type pollens were recorded beginning AD 400.

In LPAZ 6 (from AD 900 to AD 1800), AP/TLP fluctuated between 55\% and $75 \%$. Fagus, Fraxinus and Abies showed very low values. Quercus increased and fluctuated from $20 \%$ to $30 \%$. Alnus decreased to $5 \%$. The Juglans and Castanea percentages were equal to $15 \%$ and 5\%, respectively. Herbs were characterized by high values of Poaceae and ruderal and pastoral weeds but also by an increase of wild grasses. Cannabis reached its highest values. Cereals were steadily present.

In LPAZ 7 (from AD 1800 to the present), AP/TLP decreased to its lowest values (40\%) and increased again to 75\%. Betula, Alnus, Corylus, Pinus, and Quercus followed the same trend as AP/TLP, while Juniperus, Salix, Fraxinus, Fagus and Carpinus increased. Juglans decreased to 5\%. The Acer, Ulmus, Tilia, Abies and Castanea percentages did not vary. Among the herbs, Poaceae reached $40 \%$ and decreased to $15 \%$ at the end of the zone. Cannabis percentages decreased abruptly and strongly. Cereals decreased, and the values of ruderal and pastoral weeds slightly decreased.

\subsection{Charcoal record}

Four main phases of macro- and micro-CHAR variations were visually delimited (Fig. 4).

Zone $C 1$ (from 8000 to $2800 \mathrm{BC}$ ) was characterized by numerous fire episodes documented by macro-CHAR values. Macro-CHAR background was relatively high (in particular, between 6500 and 3500 $\mathrm{BC}$ ). Fire frequency reached a maximum value for the entire sedimentary record with 2 to 4 fire episodes per millennium, i.e., one fire episode every 250 to 500 years. Inversely, micro-CHAR values stayed low and no significant fluctuation was recorded during phase $\mathrm{C} 1$.

In zone $\mathrm{C} 2$ (from 2800 to $700 \mathrm{BC}$ ), macro-CHAR exhibited 3 phases of higher values at approximately 2700-2300 BC, 2000-1600 BC and $1400-700 \mathrm{BC}$. The macro-CHAR background increased, showing a maximum of biomass burned. The fire frequency was also relatively high, with approximately 3 fire episodes per millennium. Simultaneously, increases of micro-CHAR were recorded, but these increases were smaller than the macro-CHAR increases.

In zone C3 (from 700 BC to AD 600), the macro-CHAR values, background and fire frequency decreased to very low values (1-2 episodes/ 1000 years), while the micro-CHAR exhibited a series of increases.

In zone $\mathrm{C} 4$ (from AD 600 to the present), the macro-CHAR values stayed relatively low except for a few peaks of medium amplitude that indicated a higher frequency of fires (between 2.2 and 2.5 episodes/1000 years) However, the biomass burned estimated using macro-CHAR background appeared to be very low. The micro-CHAR data suggested an alternative reconstruction of the fire history, with a large increase in its values marked by successive increases of high amplitude.

\subsection{Sediment record}

The sediments of Lake Paladru have been formed from autochthonous carbonates and allochthonous inputs. As the substratum of the watershed consists primarily of detrital carbonate formations such as molasse and moraine, allochtonous inputs are relatively easy to differentiate by virtue of their richness in Fe, K, Ti, and Si (Fig. 5), and increases in these elements can be interpreted as indications of the erosion of soil from the watershed.

From 8000 to $200 \mathrm{BC}$, the autochthonous carbonates dominated the sedimentation in the lake, while terrigenous inputs to the lake remained very low. After $200 \mathrm{BC}$, an initial strong and rapid increase of the level of terrigenous elements was recorded, followed by a new phase of

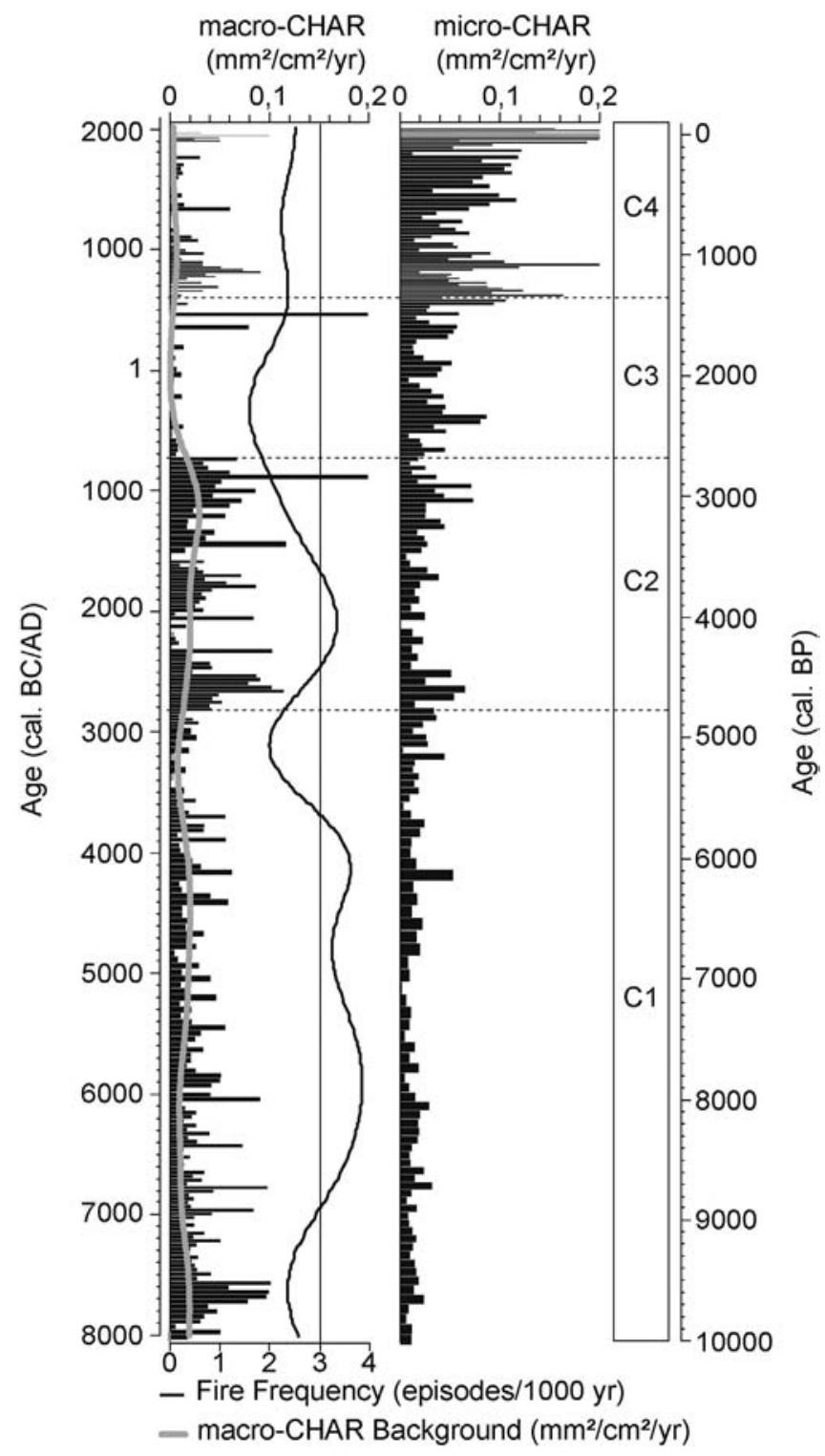

Fig. 4. Charcoal accumulation rate of microscopic charcoals (micro-CHAR) and macroscopic charcoals (macro-CHAR), with macro-CHAR background (grey line) and fire frequency per 1000 year window (black line) from Lake Paladru PAL09-MC core.

increase with higher values and extending from AD 1 to AD 400. Two subsequent phases of substantial increases were then recorded: from AD 600 to $A D 700$ and from AD 850 to the present.

\section{Discussion}

5.1. 10,000 years of land use and land cover changes: causes and consequences

For the Holocene period, five main phases of land use and land cover changes around Lake Paladru were identified combining the results previously described for each proxy (Fig 6).

\subsubsection{0 to 4200 BC: from the Mesolithic to the Middle Neolithic}

Over the Mesolithic period, just as was the case during the Early Neolithic and at the beginning of the Middle Neolithic, no evidence of human activity was revealed by the pollen analysis. This result suggests an absence of human settlements around Lake Paladru during these 3 time intervals. These results are consistent with local and regional palaeoenvironmental and archaeological data that have documented 


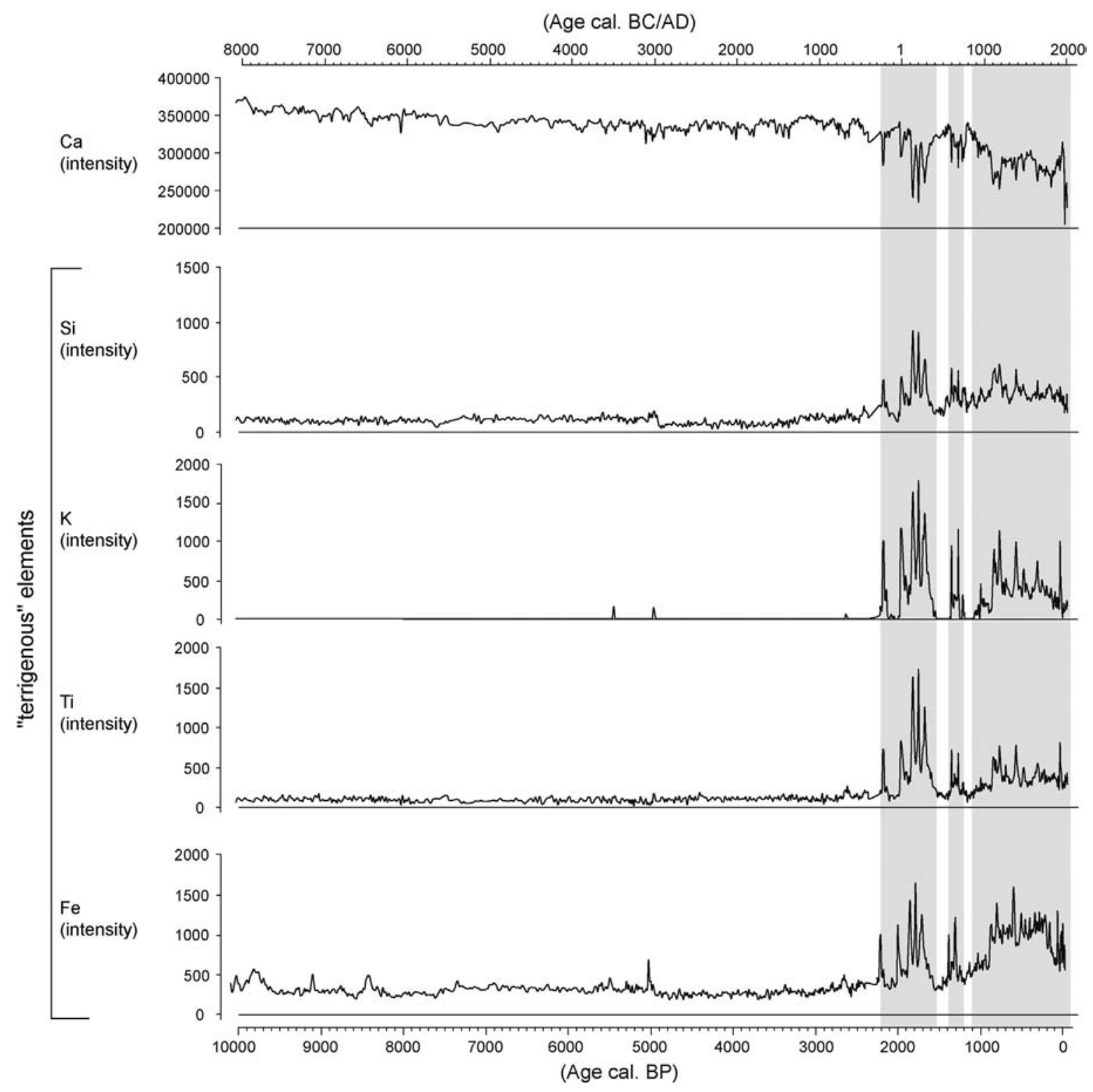

Fig. 5. Results of ITRAX analysis of calcium (Ca), silicon (Si), potassium (K), titanium (Ti) and iron (Fe) values of the PAL09-MC sediments.

an absence of lake-dwelling sites next to subalpine lakes over the Early Neolithic or only rare archaeological discoveries during the first half of the Middle Neolithic period (Marguet et al., 2008). During these periods, the surrounding vegetation mainly consisted of closed mixed deciduous woodland dominated by oak and hazelnut. Simonneau et al. (2013) have also demonstrated that local watershed land-cover disturbances were reduced around Lake Paladru and that only climate-induced changes occurred over the Early Holocene. Additionally, the climate optimum for this type of mixed-oak forest is characterized by warm summer temperatures, a pattern that is consistent with the Holocene Thermal Maximum (11,000 to 5000 years ago), extensively documented throughout the Alps during this period (Davis et al., 2003; Renssen et al., 2012). The macro-CHAR fire frequency was generally $>3$ fire episodes per millennium. This recurrence pattern could then be considered the natural regime in this region over the early and mid-Holocene. Indeed, such values are consistent with previous studies of this period conducted in the Alps or the Pyrenees (Kaltenrieder et al., 2010; Rius et al., 2011, 2012). The Holocene Thermal Maximum could also, therefore, have offered suitable conditions for fires to repeatedly start and spread at regional scales. Inversely, the low micro-CHAR recorded during this period could be associated with the difficulty of observing a relatively low level of regional fire activity due to the closed forest landscape, which filters out airborne particulates (Blackford, 2000).

\subsubsection{0 to 700 BC: From the middle Neolithic to the iron age}

After 4200 BC, following a phase with dominance of Abies and Fagus, fir-beech forest replaced oak forest in the vicinity of the lake. The concomitant increases in the percentages of the pollen of ruderal plants (P. lanceolata, Plantago major/media, Rumex-type, Urticaceae and Papaveraceae), the first occurrences of cereal pollens (from 4100 to $3000 \mathrm{BC}$; at $2550 \mathrm{BC}$; from 1300 to $1150 \mathrm{BC}$ ) and the decrease in the percentages of several pollen trees (mainly fir, beech and oak) indicated that forests were being cleared and open areas developed for arable and pastoral farming. Fire activity was characterized by low-amplitude micro-CHAR signal and a macro-CHAR fire frequency around 3 fire episodes per millennium from 4200 to $2800 \mathrm{BC}$, which furnished evidence of several fire episodes occurring in the vicinity of Lake Paladru. As argued above, these episodes may be related to the natural fire regime. However, the observed clearings and the percentages of anthropogenic pollen indicators suggest a possible early human control of the fire regime. From 2800 to 700 BC, 3 successive high-amplitude phases of micro- and macro-CHAR were recorded, with an increase in CHAR 


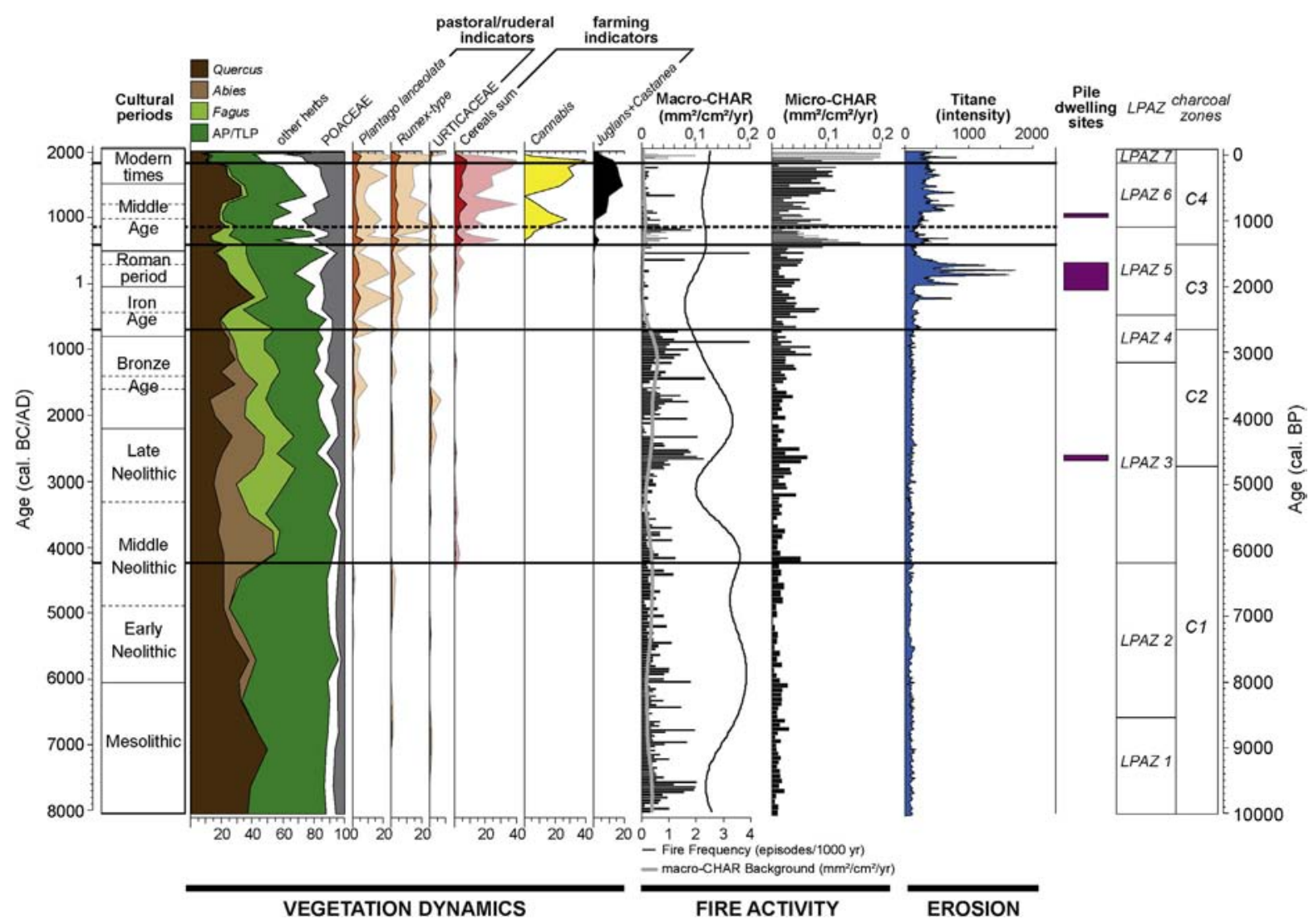

Fig. 6. Correlation of vegetation dynamics (selected taxa), fire activity and variation in soil erosion for PAL09-MC core of Lake Paladru during the last 10,000 years.

background and fire frequency. The CHAR background suggested that biomass burning was more frequent during the previous period but that the frequency of fires appeared to be lower than that hypothesized for the natural fire regime recorded between 7000 and 4000 BC. This new fire regime was more clearly associated with land use, namely, the development of agropastoral activities around the lake (Fig. 6). These results appear to be consistent with human practices revealed by pollen studies performed at the archaeological site "Les Baigneurs" (2750 to 2650 BC; Fig. 1c) (Emery-Barbier, 1984) located on the lake shore and at other contemporary pile-dwelling sites in the Alps and Alpine arc (Marguet et al., 2008; Pétrequin and Pétrequin, 1988). The discontinuity in cereal, ruderal and pastoral weed occurrences, and the fluctuations of the percentage of arboreal taxa and of fire regimes (Fig. 6) could be related to the cyclical nature of successive human occupations marked by land clearing for farming development until soil depletion, land abandonment and forest regeneration occurred. Certain features, such as the decrease in fire activity, the lack of cereal pollens and the development of beech (between 3400 and $2800 \mathrm{BC}, 2300$ and $2100 \mathrm{BC}$ and from 1600 to $1500 \mathrm{BC}$ ) may, therefore, be interpreted as evidence of a temporary displacement of the population from the shores of Lake Paladru to neighbouring areas. Some evidence of such human settlement strategies has been found for the 3rd millennium BC in the record from the Chirens peat bog. This bog is located a distance of $6 \mathrm{~km}$ from Lake Paladru (Bocquet, 2012). These population displacements from one area to another, perhaps to prevent the overexploitation of their local environment or related to climate variation, appear to be integral to the way of life of farming communities at that time (Bocquet, 1987; Pétrequin et al., 2000).

The absence of soil erosion in these successive human settlements may indicate that the human pressure was not sufficiently intense or prolonged to significantly impact soils in the watershed. The repeated use of fire and the harvest of wood (primarily fir) for construction or domestic use (Emery-Barbier, 1984; Bocquet, 1987) could have caused the virtual disappearance of fir and the decrease of beech cover in favour of oak cover at the end of this period. Similar collapses of fir were recorded earlier, from the middle of the Holocene (around 4000 and 2000 BC), in several sites in French and Switzerland Alps (Carcaillet and Muller, 2005; Colombaroli et al., 2007; Tinner et al., 1999).

Finally, the occupation of the archaeological site "Les Baigneurs" was recorded by the results of the pollen and charcoal analyses and appears to be integrated into larger periods of settlement in the watershed through the Middle Neolithic to the Bronze Age. No archaeological site prior to the "Les Baigneurs" site has been discovered on the lake shores, but previous pollen data from a littoral core (Emery-Barbier, 1984) has provided suggestive evidence of human influence during the thousand years prior to the occupation of this archaeological site. Evidence of Bronze Age occupation has only been supported locally by 2 archaeological artefacts (approximately $1000 \mathrm{BC}$ ). However, evidence of the development of agrarian activities during the Bronze Age has also been supported by the presence of miliacin concentrations in sediments from $1550 \mathrm{BC}$, which suggest the initial development of millet cultivation in the watershed (Simonneau et al., 2013).

\subsubsection{BC to $A D$ 600: From the iron age to the Roman period}

The pollen analyses performed in the current study showed an intensification of tree clearing (beech, fir, ash and elm) during the Iron Age and the Roman period and a greater development of plants associated with open landscapes and, more precisely, with pasture areas (P. lanceolata, Rumex-type, Urticaceae, P. major/media, Papaveraceae). No pollen indicators of cereal production during the first Iron Age were identified, whereas a low but continuous pollen curve of cereals during the second Iron Age and the Roman period was recorded and certainly corresponded to the development of crop farming. Several increases in micro-CHAR were recorded synchronously with an increase of pollen pasture areas and occurrences of cereals (Cerealia-type and Secale-type), whereas macro-CHAR markedly decreased. These records 
could indicate new deforestation due to fire at the regional scale, in higher-elevation areas, for example, while the landscape in the vicinity of the lake was already open. Periods of enhanced soil erosion dating from $200 \mathrm{BC}$ and from $\mathrm{AD} 1$ to $\mathrm{AD} 400$ reflected the intensification of human activities throughout the catchment area with the expansion of crop farming and, certainly, the emergence of an "extensive system" of fixed fields (Brombacher et al., 2013). These results are, therefore, consistent with previous data published by Doyen et al. (2013a) on Lake Moras and confirm that the second Iron Age and the Roman period represent key periods of landscape shaping at a regional scale.

The effects of human activity recorded for the Iron Age are not supported by archaeological discoveries on the lake shores or in the watershed. In contrast, those effects recorded during the Roman period, characterized by a stronger erosion signal, are supported by numerous archaeological artefacts, primarily on the lake shores (Dècle and Verdel, 2012). Moreover, the establishment of the "Allobroge" people since $350 \mathrm{BC}$, at a regional scale, was characterized by an increase in the number of archaeological sites. This trend continued after the Roman conquest (121 BC), until the early Roman period (Bernigaud, 2012; Bertrandy et al., 2011).

After AD 350, previously open areas (pastures and fields) were afforested, as shown by the development of riparian vegetation (alder and birch) and trees (beech and hornbeam). This apparent reduction of human impact on local landscapes is also suggested by micro-CHAR and soil erosion decreases. However, enhanced erosion phases appear to have occurred within the catchment of Lake Paladru during this period (Borel et al., 1994; Brochier et al., 2007; Simonneau et al., 2013). Those authors claimed that it was linked to an extension of human land use to previously undeveloped areas. The apparent local land abandonment detected through the pollen spectrum and also recorded in the upper Rhone valley from AD 200 to AD 400 (Berger, 2010; Doyen et al., 2013a) could, therefore, be explained by a reorganization of agrarian production and farmland, consisting of a reforestation of some areas and the opening of others potentially closer to the lake. At the regional scale, such phases of reorganization were already documented during the 4 th and 5 th centuries CE. These phases produced a demographic decrease in areas distant from larger urban places (Dècle and Verdel, 2012).

\subsection{4. $A D 600$ to $A D$ 1800: From the middle age to modern times}

Agropastoral activities were marked beginning with the Middle Ages, clearly recorded with the expansion of crop farming, the apparition of wheat and rye pollens, and a diversification of agricultural activities such as tree farming, hemp cultivation and retting, or buckwheat cultivation. At the same time, micro-CHAR reached the highest values from the past 10,000 years, synchronously with slight increases of macro-CHAR and fire frequency. Agricultural activities did not change during this period, but several fluctuations within the pollen spectra, the fire activity record and the soil erosion suggested that local human pressure varied to a certain extent and can be distinguished in two phases.

5.1.4.1. From $A D 600$ to $A D 850$. Forest clearing, together with the diversification and development of crop and tree farming, were evident from $\mathrm{AD} 600$ to $\mathrm{AD} 700$, and livestock farming continued. In parallel to these patterns, the increases in macro-CHAR and micro-CHAR particularly demonstrated fire use for new clearing of forests after afforestation during the previous period and agrarian areas maintenance. Simultaneously, a new increase in terrigenous elements was recorded, demonstrating enhanced soil erosion associated with clearing and the development of additional agrarian land within the watershed. These human impacts have been confirmed by other palaeoenvironmental studies (from AD 550 to $\mathrm{AD} 800$ ) conducted in the littoral zone and in the central portion of the lake (Brochier et al., 2007; Simonneau et al., 2013). These results verified the development of local anthropogenic activities in the watershed of Lake Paladru at the beginning of the Middle Ages despite the lack of local archaeological data for this period. This new expansion of human activities was certainly linked to a political re-organization and new economic strategies generated by the fall of the Roman Empire and the power takeover by the Burgundians and then by the Franks during the 6th century AD. The intensification and the diversification of agricultural practices have also been recorded regionally (Berger, 2010; Doyen et al., 2013a).

A brief increase observed in several arboreal taxa representing forest (oak) and riparian vegetation (alder, birch and ash) and decreases in micro-CHAR and soil erosion from AD 700 to AD 850 suggested a reduction of human pressure on the local environment but also a reorganization of agricultural practices. The introduction and the development of hemp cultivation (Cannabis) could have induced changes in farmland management without necessarily producing new clearings but, perhaps, the reforestation of some areas (Rasmussen, 2005).

5.1.4.2. From $A D 850$ to $A D$ 1800. From AD 850, a new expansion of land clearing, mainly illustrated by the reduction of alder, oak and beech cover, was associated with an increase in grazing and farming pollen indicators (cereals and hemp). Tree farming, consisting of walnut and chestnut cultivation, expanded after AD 1000. Further increases in fire signals, especially an influx of micro-CHAR, reflected a renewal of regional fire activity, whereas the slight increase of fire frequency marked the re-use of fire at the local scale. Soil erosion also progressively increased and remained at a high level from AD 1100 to the present. All these palaeoenvironmental proxies illustrate increasing human influences on the local and regional environments of Lake Paladru, with the pressure and the nature of human activities remaining similar until AD 1900.

The same trend was also evident for 9th and 10th centuries AD based on the palaeoenvironmental data obtained from the core taken the lake shore (Brochier et al., 2007). The occupation of the pile-dwelling sites during the 11 th century AD appears to be a continuous extension of these settlements dating from the 9th century AD. Human activities identified by palaeoenvironmental data are also consistent with most of those detected via archaeological data for the site of "Colletière" (from AD 1000 to AD 1030; Colardelle and Verdel, 1993; Lundstrom-Baudais and Mignot, 1992), including crops and livestock farming, harvesting nuts (walnuts and chestnuts), hemp production and the collection of wood for building, handicrafts or fuel (mainly oak and beech). All these activities could have caused the strong and unprecedented decrease of beech in favour of oak. After these settlements, the establishment of human occupancy of the lake shores continues to be verified by archaeological and historical data, e.g., the founding of a monastery during the 12th century $\mathrm{AD}$ and the development of craft activities during the 14th century AD in adjacent valleys ( $c f .2 .2$. Archaeological and historical settings). Thus, the historical citations of the use of tools for threshing hemp verified the development of economic activity that was focused on a textile fibre, namely, hemp, from the 14 th to the 19 th centuries AD around the lake (Colardelle and Verdel, 2002).

5.1.5. From $A D 1800$ to the present: contemporary times to the current era

All agrarian activities practiced from the beginning of the Middle Ages decreased, whereas the percentages of open-land herbs continued to increase, suggesting that a large proportion of farmland was replaced by grazing land, whereas residual areas of forest were cleared (AP/TLP reached its lowest values). These land-use modifications were certainly spurred by the development of industrial activity during the 18th-19th centuries AD at the expense of farming activities (Colardelle and Verdel, 2002). The substantial consumption of wood by these industries could certainly have caused the extensive clearing recorded during the 19th and 20th centuries AD. In parallel, the micro-CHAR influxes reflected the emission of charred particles by numerous industries and the combustion of wood charcoal despite the increasing use of coke as fuel. 
During the present period, forested areas have increased again with the establishment of the present forest cover ( $c f .2 .1$. Environmental settings). Grassland areas are still present, and farming has remained underdeveloped. The need for fuel decreased with the disappearance of most industrial activities in the mid-20th century AD.

\subsection{Relationship between the occurrence of fire and land use changes}

The reconstruction of fire histories and the quantification of fire occurrences offer a potential approach of interest to the processes and rhythms of human impacts (Rius et al., 2009; Tinner et al., 2003; Vannière and Martineau, 2005). The past history of fires around the lake can be reconstructed at different spatial scales with an approach combining micro and macro-charcoal analyses. Macro-charcoal analysis is used to detect fires within a radius of approximately one kilometre around the lake (Higuera et al., 2007), whereas micro-charcoals, which easily travel long distances, facilitate the reconstruction of the regional fire history within a radius of approximately 10 to $100 \mathrm{~km}$ around the lake (Tinner et al., 1998).

The reconstitution of human impacts around Lake Paladru is marked by a major change in the sizes of charcoal particles at approximately 700 BC (Figs. 4 and 6).

From 4200 to $700 \mathrm{BC}$ (Fig. 6), both increases of micro- and macroCHAR fluxes were recorded; however, macro-CHAR fluctuations were dominant compared with the micro-CHAR ones, especially from 2800 to $700 \mathrm{BC}$. This type of fire signal appears to reflect agricultural activities, primarily based on slash-and-burn practices and corresponding to the first human impacts recorded around the lake. In certain areas of Europe (the Aosta valley in Italy, Jura; Pétrequin et al., 2006), the use of the swing plough is documented for this period. However, the heaviness and the density of the soils appear to have prevented the use of this tool in the Lake Paladru watershed and favoured slash-and-burn practices in a forest with thinned undergrowth (Bocquet, 2012). The predominance of macro-CHAR compared to micro-CHAR can be explained by several factors: (i) the type of fire (for land clearing) and fuel (primarily trees) may have generated relatively large charcoal particles; (ii) the quantity of micro-charcoals generated by fires for land clearing is not sufficient to be isolated from the micro-CHAR background noise given the limited expansion of human settlements during this period; or (iii) during the Neolithic, the dense and extensive forest certainly favoured the local emission of macro-charcoals and limited the regional contribution of micro-charcoals. In comparison, the increase in micro-CHAR associated with periods of human impact also remained low during the Neolithic and the Bronze Age in Lake Moras (Doyen et al., 2013a) as in other lakes of the Northern Alps (Tinner et al., 2005).

From $700 \mathrm{BC}$ to the present, micro-CHAR fluctuations had a higher magnitude (Fig. 6), whereas the macro-CHAR fluctuations were null or of low magnitude. This modification in the particle types recorded in lacustrine sediments was synchronous with enhanced human pressure within the catchment area of Lake Paladru, as shown by pollen and soil erosion data. The change of agricultural practices from a "forest agrarian" system (forest fallow) to a "post-forest agrarian" system (grassy fallow) certainly involved a transformation in the type of fire use. Fire was less frequently used as a tool to develop agrarian areas because the landscape had been permanently deforested since the Iron Age (Brombacher et al., 2013). From this period, fire was most likely reserved for the maintenance of open agropastoral areas (Vannière and Martineau, 2005). This change in fire use may have induced a change in the type of fuel and in the size of charcoal produced. For instance, Rius et al. (2009) recorded a decrease of macro-CHAR during the same period in the Pyrenees. The apparent reasons for this decrease are a change of practices and a decrease of the fuel biomass available. The dominance of micro-CHAR values compared to macro-CHAR ones could also be linked to an increase in the regional contribution. Indeed, the expansion of human activities throughout this period in association with population growth has generated extremely open landscapes, facilitating the dispersion of micro-CHAR (Doyen et al., 2013a; Stähli et al., 2006).

The marked increase of the micro-CHAR signal during the modern period (from AD 1850 to the present; Fig. 6) could be linked to industrialization and the emission of charcoal particles by industries. This increase in fire activity is synchronous with the re-organization of agricultural activities in the catchment area, as recorded by pollen data. It highlights a new historical change in fire use in association with the recent modifications of human activities and socio-economic needs.

\section{Conclusions}

The multi-proxy study performed on the sedimentary sequence cored from central Lake Paladru makes it possible to place numerous local archaeological excavations and historical findings in a regional context, specifically, that of anthropogenic impact from the Mesolithic to the present. Several periods of anthropogenic impacts during the Middle Neolithic, the Bronze Age and the Iron Age, not previously supported by archaeological discoveries, have been identified by this study.

The first anthropogenic impacts, of low intensity, have been recorded during the Middle Neolithic prior to the occupation of the archaeological site "Les Baigneurs". Thus, the occupation of this archaeological site was, in fact, a part of a successive cyclic development of agropastoral activities and fire use around the lake from the Middle Neolithic to the Bronze Age. The development of grazing and farming practices around the lake persisted during the Iron Age and the Roman period, with a modification in the nature of agrarian practices identified by a lower use of fire around the lake and an unprecedented increase in soil erosion. This important phase of soil erosion is contemporary with numerous archaeological traces of human settlement of the lake shores during the Roman period. These results obtained for Lake Paladru confirmed the hypothesis that this period from the end of the Iron Age and the Roman period appears to be a key period of landscape modification linked to vegetation and soil disturbances, at least in the Upper Rhone valley, as suggested by the increase in soil erosion identified concomitantly in Lake Moras, a distance of $30 \mathrm{~km}$ away (Doyen et al., 2013a).

A phase of expansion and diversification in agropastoral practices is recorded during the 9th and 10th centuries AD previous to the occupation of pile-dwelling sites such as the archaeological site of "Colletière" during the 11th century AD. Thus, these settlements seem to be integrated in a general dynamic of the expansion of agropastoral practices in the watershed, maintained until the 18 th century. During this period, most of the anthropogenic practices recorded during the Medieval period disappeared and were replaced by a new system of landscape modification linked to the expansion of industrial activities, as documented by historical writings.

The parallel study of micro- and macro-charcoals in the same sedimentary sequence is highly pertinent for establishing changes in fire use and to determine the type of biomass burned and the origin of charcoals. These modifications are synchronous with changes in agropastoral practices throughout history and especially in connection with the passage from a forest agrarian system (forest fallow) to a post-forest agrarian system (grassy fallow) during the Iron Age.

\section{Acknowledgements}

This study was conducted within the framework of the ANR PYGMALION. We are grateful to Stock A, Fanget B and Mallet E for their help with the field work. We also thank Tachikawa K and Bard E for allowing us to perform the ITRAX analyses at CEREGE laboratory and Garcia M for advice during the analysis. We thank the LM14C for the radiocarbon dating performed within the framework of the INSU ARTEMIS call for proposals. We thank Daniele Colombaroli and an anonymous reviewer for the evaluation of the manuscript. 


\section{References}

Ali, A.A., Blarquez, O., Girardin, M.-P., Hély, C., Tinquaut, F., 2012. Control of the multimillennial wildfire size in boreal North America by spring climatic conditions. PNAS 109, 20966-20970.

Berger, J.-F., 2010. Peuplement et Milieu en bas Dauphiné (Isle Crémieu) de l'apparition de l'agriculture à l'époque moderne. Rapport d'activité final de triennale du PCR. Peuplement et Milieu en bas-Dauphiné, Ile Crémieu, de l'apparition de l'agriculture à l'époque moderne.

Bernigaud, N., 2012. Les anthroposystèmes des marais de Bourgoin-la Verpillère (Isère) du Néolithique final à l'Antiquité tardive (Thèse) Université de Sophia Antipolis, Nice.

Bertrandy, F., Bleu, S., Jospin, J.-P., Royet, R., 2011. Carte archéologique de la Gaule, l'Isère, arrondissement de La Tour-du-Pin, 38/2. Académie des Inscriptions et Belles-Lettres, Paris.

Beug, H.-J., 2004. Leitfaden der Pollenbestimmung für Mitteleuropa und angrenzende Gebiet. Pfiel, München.

Blaauw, M., 2010. Methods and code for "classical" age-modelling of radiocarbon sequences. Quat. Geochronol. 5, 512-518.

Blackford, J.J., 2000. Charcoal fragments in surface samples following a fire and the implications for interpretation of subfossil charcoal data. Palaeogeogr. Palaeoclimatol. Palaeoecol. 164, 33-42.

Blarquez, O., Girardin, M.-P., Leys, B., Ali, A.A., Aleman, J.-C., 2013. Paleofire reconstruction based on an ensemble-member strategy applied to sedimentary charcoal. Geophys. Res. Lett. 40, 2667-2672.

Bocquet, A., 1974. Un village de la fin du Néolithique en Dauphiné: la station des Baigneurs à Charavines [campagne 1973]. Bull.Acad. Delphinale 3, 78-80.

Bocquet, A., 1987. L'homme, la forêt, le bois il y a 5.000 ans. Rev. For. Fr. 39, 457-464.

Bocquet, A., 2012. Les oubliés du lac de Paladru: ils dormaient depuis 5000 ans en Dauphiné. La Fontaine de Siloé, Montmélian-en-Savoie.

Bocquet, A., Brochier, J.-L., Emery-Barbier, A., 1987. A submerged neolithic village: Charavines "Les Baigneurs» in lake Paladru, France. In: Coles, J.M., Lawson, A.J. (Eds.), European wetlands in Prehistory. Clarendon Press, Oxford, pp. 33-54.

Borel, J.L., Brochier, J.L., Druart, J.C., 1994. Microlaminations lacustres: variations bathymétriques et climatiques avant l'An mil sur le site de Colletière, Lac de Paladru, France. Quaternaire 5, 105-111.

Brochier, J.-L., Borel, J.-L., Druart, J.-C., 2007. Les variations paléoenvironnementales de 1000 avant à 1000 après J.C. et la question des "optima» climatiques de l'Antiquité tardive et du Moyen Age sur le piémont des Alpes du nord à Colletière, lac de Paladru, France. Quaternaire 18, 253-270.

Brombacher, C., Guélat, M., Thew, N., 2013. Changements environnementaux intervenus dans la chaîne jurasienne entre le Néolithique et l'âge du Fer. Aspects archéobotaniques, malacologiques et géologiques. In: Richard, A., Schifferdecker, F Mazimann, J.-P., Bélet-Gonda, C. (Eds.), Deuxièmes journées archéologiques frontalières de l'Arc jurassien. Actes des rencontres 2007Cahier d'archéologie jurassienne Vol. 21. Office de la culture et Société jurassienne d'Emulation, Porrentruy, pp. 155-174.

Carcaillet, C., Muller, S., 2005. Holocene tree-limit and distribution of Abies alba in the inner French Alps: anthropogenic or climatic changes? Boreas 34, 468-476.

Chapron, E., Simonneau, A., Ledoux, Arnaud, F. Lajeunesse, P., Albéric, P. 2015. French alpine foreland Holocene paleoseismicity revealed by coeval mass wasting deposits in glacial lakes. In: Lamarche, G. (Ed.), Submarine Mass Movements and their ConsequencesAdvances in Natural and Technological Hazards Research Vol. 41. Springer, pp. 341-349.

Clark, J.S., 1988. Particle motion and the theory of charcoal analysis: source area, transport, deposition, and sampling. Quat. Res. 30, 67-80.

Colardelle, M., Verdel, E., 1993. Les Habitats du lac de Paladru (Isère) dans leur environnement: la formation d'un terroir au Xlème siècle. Documents d'archéologie française. Editions de la Maison des Sciences et de l'Homme, Paris.

Colardelle, M., Verdel, E., 2002. L'habitat fortifié médiéval de Colletière à Charavines et le pays du Lac de Paladru : recherches archéologiques. historiques et environnementales Rapport intermédiaire.

Colombaroli, D., Marchetto, A., Tinner, W., 2007. Long-term interactions between Mediterranean climate, vegetation and fire regime at Lago di Massaciuccoli (Tuscany, Italy). J. Ecol. 95, 755-770.

Davis, B.A.S., Brewer, S., Stevenson, A.C., Guiot, J., 2003. The temperature of Europe during the Holocene reconstructed from pollen data. Quat. Sci. Rev. 22, 1701-1716.

Dearing, J.A., 2006. Climate-human-environment interactions: resolving our past. Clim. Past 2, 187-203.

Dearing, J.A., Jones, R.T., 2003. Coupling temporal and spatial dimensions of global sediment flux through lake and marine sediment records. Glob. Planet. Chang. 39, 147-168.

Dècle, J.-F., Verdel, E., 2012. Nouvelle carte de la fréquentation du lac de Paladru à l'époque gallo-romaine. In: Colardelle, M., Verdel, E. (Eds.), L'habitat fortifié médiéval de Colletière à Charavines (lac de Paladru, Isère). Rapport d'opérations 2012.

Doyen, E., Vannière, B., Berger, J.-F., Arnaud, F., Tachikawa, K., Bard, E., 2013a. Land-use changes and environmental dynamics in the upper Rhone valley since Neolithic Times inferred from sediments of Lac Moras. The Holocene 23, 961-973.

Doyen, E., Vannière, B., Bichet, V., Gauthier, E., Richard, H., Petit, C., 2013b. Vegetation history and landscape management from 6500 to $1500 \mathrm{cal}$. BP at Lac d'Antre, GalloRoman sanctuary of Villards d'Héria, Jura, France. Veg. Hist. Archaeobot. 22, 83-97.

Doyen, E., Vannière, B., Rius, D., Bégeot, C., Millet, L., 2015. Climate and biomass control on fire activity during the late-glacial/early-Holocene transition in temperate ecosystems of the upper Rhone valley (France). Quat. Res. 83, 94-104.

Emery-Barbier, A., 1984. Interprétation sommaire des analyses palynologiques. In: Bocquet, A. (Ed.), Station des Baigneurs, village néolithique immergé (Isère, Charavines, lac de Paladru). Rapport de fouille, d'études connexes et d'animations.
Enters, D., Dörfler, W., Zolitschka, B., 2008. Historical soil erosion and land-use change during the last two millennia recorded in lake sediments of Frickenhauser See, northern Bavaria, Central Germany. The Holocene 18, 243-254.

Faegri, K., Iversen, J., 1989. Textbook of Pollen Analysis. fourth ed John Wiley and Sons, Chichester.

Gauthier, E., Richard, H., Magny, M., Peyron, O., Arnaud, F., Jacob, J., Marguet, A., Billaud, Y., 2008. Le lac du Bourget (Savoie, France) à l'âge du Bronze: végétation, impact anthropiques et climat. In: Richard, H., Garcia, D. (Eds.), Le peuplement de l'arc alpin. Editions du CTHS, Paris, pp. 107-121.

Gavin, D.G., Hu, F.S., Lertzman, K., Corbett, P., 2006. Weak climatic control of stand-scale fire history during the late Holocene. Ecology 87, 1722-1732.

Higuera, P.E., Brubaker, L.B., Anderson, P.M., Hu, F.S., Brown, T.A., 2009. Vegetation mediated the impacts of postglacial climate change on fire regimes in the south-Central Brooks Range, Alaska. Ecol. Monogr. 79, 201-219.

Higuera, P.E., Peters, M.E., Brubaker, L.B., Gavin, D.G., 2007. Understanding the origin and analysis of sediment-charcoal records with a simulation model. Quat. Sci. Rev. 26, 1790-1809.

Jacomet, S., 2009. Plant economy and village life in Neolithic lake dwellings at the time of the Alpine Iceman. Veg. Hist. Archaeobot. 18, 47-59.

Kaltenrieder, P., Procacci, G., Vannière, B., Tinner, W., 2010. Vegetation and fire history of the Euganean Hills (Colli Euganei) as recorded by late glacial and Holocene sedimentary series from Lago della Costa (Northeastern Italy). The Holocene 20, 679-695.

Ledger, P.-M., Miras, Y., Poux, M., Milcent, P.-Y., 2015. The palaeoenvironmental impact of Prehistoric settlement and Proto-Historic Urbanism: Tracing the emergence of the Oppidum of Corent, Auvergne, France. PLoS One 10 (4), e0121517. http://dx.doi. org/10.1371/journal.pone.0121517.

Long, C.J., Whitlock, C., Bartlein, P.J., Millspaugh, S.H., 1998. A 9000-year fire history from the Oregon Coast Range, based on a high-resolution charcoal study. Can. J. For. Res. $28,771-787$.

Lundstrom-Baudais, K., Mignot, C., 1992. L'apport des analyses xylologiques dans la reconstitution de la mise en place de l'agrosystème vers l'An Mil à Colletière (Lac de Paladru, Isère). Bulletin de la Société Botanique de France. Actual. Bot. 139, 2-3.

Magny, M., 1993. Une nouvelle mise en perspective des sites archéologiques lacustres: les fluctuations holocènes des lacs jurassiens et subalpins. Gallia Préhistoire 35, 253-282

Marguet, A., Bintz, P., Nicod, P.-Y., Picavet, R., Rey, P.-J., Thirault, E., 2008. Elements for a settlement history of north French alps between 10000 and 2700 years BP. Cah. Paléoenviron. Collect. Edytem 6, 225-252.

Pétrequin, A.-M., Pétrequin, P., 1988. Le Néolithique des Lacs, Préhistoire des lacs de Chalain et de Clairvaux (4000-2000 av. J.-C.). Collection des Hespérides. Editions Errance, Paris.

Pétrequin, P., Arbogast, R.-M., Bourquin-Mignot, C., Duplaix, A., Martineau, R., Pétrequin, A.-M., Viellet, A., 2000. Le mythe de la stabilité: déséquilibre et réajustements d'une communauté agricole néolithique dans le Jura français, du 32e au 30e siècle av. J.C. In: Richard, H., Vignot, A. (Eds.), Equilibres et ruptures dans les écosystèmes depuis 20000 ans en Europe de l'Ouest. Presse universitaire franc-comtoise, Besançon.

Pétrequin, P., Arbogast, R.-M., Pétrequin, A.-M., VanWilligen, S., Bailly, M., 2006. Premiers chariots, premières araires. La diffusion de la traction animale en Europe pendant les IVe et IIIe millénaires avant notre ère. CNRS Editions, Paris, CRA 29.

Rasmussen, P., 2005. Mid-to late-Holocene land-use change and lake development at Dallund S0, Denmark: vegetation and land-use history inferred from pollen data. The Holocene 15, 1116-1129.

Reille, M., 1992. Pollen et spores d'Europe et d'Afrique du Nord. Laboratoire de Botanique Historique et Palynologie, Aix-Marseille.

Renssen, H., Seppä, H., Crosta, X., Goosse, H., Roche, D.M., 2012. Global characterization of the Holocene thermal maximum. Quat. Sci. Rev. 48, 7-19.

Rhodes, A.N., 1998. A method for the preparation and quantification of microscopic charcoal from terrestrial and lacustrine sediment cores. The Holocene 8, 113-117.

Richard, H., 1997. Analyse pollinique d'un sondage de 7,50 m. In: Pétrequin, P. (Ed.)Les sites littoraux néolithiques de Clairvaux et de Chalain (Jura), Chalain station 3, 3200-2900 av. JC, tome III vol. 1. Edition Maison des sciences de l'Homme, Paris, pp. 101-112.

Rius, D., Vannière, B., Galop, D., 2009. Fire frequency and landscape management in the north-western Pyrenean piedmont (France) since the early Neolithic (8000 cal. BP). The Holocene 19, 847-859.

Rius, D., Vannière, B., Galop, D., 2012. Holocene history of fire, vegetation and land use from the central Pyrenees (France). Quat. Res. 77, 54-64.

Rius, D., Vannière, B., Galop, D., Richard, H., 2011. Holocene fire regime changes from multiple-site sedimentary charcoal analyses in the Lourdes basin (Pyrenees, France). Quat. Sci. Rev. 30, 1696-1709.

Rösch, M., 1992. Human impact as registered in the pollen record: some results from the western lake Constance region, Southern Germany. Veg. Hist. Archaeobot. 1, 100-109.

Seddon, A.W., Mackay, A.W., Baker, A.G., Birks, H.J.B., Breman, E., Buck, C.E., ... LarocqueTobler, I., 2014. Looking forward through the past: identification of 50 priority research questions in palaeoecology. J. Ecol. 102, 256-267.

Simonneau, A., Doyen, E., Chapron, E., Millet, L., Vannière, B., Di Giovanni, C., Bossard, N., Tachikawa, K., Bard, E., Albéric, P., Roux, G., Lajeunesse, P., Berger, J.-F., Arnaud, F., 2013. Holocene land-use evolution and associated soil erosion in the French Prealps inferred from Lake Paladru sediments and archaeological evidences. J. Archaeol. Sci. 40, 1636-1645.

Stähli, M., Finsinger, W., Tinner, W., Allgower, B., 2006. Wildfire history and fire ecology of the Swiss National Park (Central Alps): new evidence from charcoal, pollen and plant macrofossils. The Holocene 16, 805-817.

Stockmaar, J., 1971. Tablets with spores used in absolute pollen analysis. Pollen Spores 13 615-621.

Tinner, W., Conedera, M., Ammann, B., Gaggeler, H.W., Gedye, S., Jones, R., Sagesser, B. 1998. Pollen and charcoal in lake sediments compared with historically documented forest fires in Southern Switzerland since AD 1920. The Holocene 8, 31-42. 
Tinner, W., Conedera, M., Brigitta, A., Lotter, A.F., 2005. Fire ecology north and south to the alps since the last ice age. The Holocene 15, 1214-1226.

Tinner, W., Hubschmid, P., Wehrli, M., Ammann, B., Conedera, M., 1999. Long-term forest fire ecology and dynamics in Southern Switzerland. J. Ecol. 87, 273-289.

Tinner, W., Lotter, A., Ammann, B., Conedera, M., Hubschmid, P., van Leeuwen, F., Wehrli, M., 2003. Climatic change and contemporaneous land-use phases north and south of the Alps. Quat. Sci. Rev. 22, 1447-1460.

Turner, R., Kelly, A., Neils, R., 2008. A critical assessment and experimental comparison of microscopic charcoal extraction methods. In: Fiorentino, G., Magri, D.
(Eds.), Proceedings of the Third International Meeting of Anthracology. Archaeopress, Oxford, pp. 265-272.

Umbanhowar, C.E., McGrath, M.J., 1998. Experimental production and analysis of microscopic charcoal from wood, leaves and grasses. The Holocene 8, 341-346.

Vannière, B., Martineau, R., 2005. Histoire des feux et pratiques agraires du Néolithique à l'âge du Fer en région Centre: implications territoriales, démographiques et environnementales. Gallia Préhistoire 47, 167-186. 